\title{
Optical Rotations, Refractive Indices, and Densities of Dextran Solutions
}

\author{
C. F. Snyder, H. S. Isbell, M. R. Dryden, and N. B. Holt
}

\begin{abstract}
Clinical dextrans obtained from commercial sources, using different strains of Leuconostoc mesenteroides, were found to vary in optical rotation $\left([\alpha]_{5893 \mathrm{~A}}^{20} \mathrm{~A}\right)$ from $+194.6^{\circ}$ to $+211.0^{\circ}$. Samples derived from the same strain of bacteria, however, did not differ widely. With few exceptions, all samples of clinical dextran derived from the Northern Utilization Research Branch of the Agriculture Research Service (formerly Northern Regional Research Laboratory), B512 strain of Leuconostoc mesenteroides, have values in water solutions of $[\alpha]_{5893 \mathrm{~A}}^{20^{\circ} \mathrm{C}}=$ $+199^{\circ} \pm 2^{\circ}$ and $[\alpha]_{5461 \mathrm{~A}}^{20^{\circ} \mathrm{C}}=+235^{\circ} \pm 1^{\circ}$. The specific rotation was found to vary with temperature, in the range $15^{\circ}$ to $30^{\circ} \mathrm{C}$, according to the equation
\end{abstract}

$$
[\alpha]_{5893 \mathrm{~A}}^{20^{\circ} \mathrm{C}}=[\alpha]_{5893 \mathrm{~A}}^{t}(1+0.00033(t-20)) .
$$

The presence of 0.9 percent of sodium chloride or less than 10 percent of methanol did not alter the optical rotation of aqueous dextran appreciably; 40-percent methanol solution caused an increase of about 1 percent.

The factor for converting quartz-wedge-saccharimeter readings of dextran solutions to angular degrees and sodium light was determined and found to agree with the factor $(0.3462)$ ordinarily used for sugar solutions.

Measurements of refractive index and of apparent density in air gave the following equations: $n_{5 \times 93 \mathrm{~A}}^{20^{\circ}}=1.33299+0.00151 p+0.0000064 p^{2}$, and $d_{20^{\circ} \mathrm{C}}=0.99717+0.00398 p+$

$0.000016 p^{2}$, where $p$ is the number of grams of dextran in $100 \mathrm{~g}$ of aqueous solution (weights in air). Tables of refractive indices and apparent densities are given for aqueous solutions and for solutions containing 0.9 and 0.3 percent $\mathrm{W} / \mathrm{V}$ of sodium chloride. ${ }^{2}$

\section{Introduction}

According to the present specification of the Armed Services Medical Procurement Agency, clinical dextran is prepared from the polysaccharide formed from sucrose by Leuconostoc mesenteroides, strain B512. The polysaccharide is partially hydrolyzed and the material having a weight-average molecular weight of $75,000 \pm 25,000$ is separated by fractional precipitation with aqueous methanol, ethanol, or acetone. Ordinarily clinical dextran is dispensed in a 6-percent solution, containing $0.9 \mathrm{~g}$ of sodium chloride per $100 \mathrm{ml}$. To insure a safe and effective blood-plasma extender, reliable and accurate methods of analysis must be used for control of the manufacturing process and for evaluation of the finished product [1]. ${ }^{3}$ The present investigation is confined to the consideration of clinical material having the above characteristics, except where otherwise stated.

It has been established by prior workers [2] that dextrans produced by various strains of Leuconostoc mesenteroides differ widely. The results reported here are based on samples of clinical dextran supplied us by manufacturers and the Armed Services Medical

\footnotetext{
1 This work was supported in part by the Medical Research and Development Board, Office of the Surgeon General, Department of the Army. It was carried out under the Plasma Volume Expanders Program of the Subcommittee on Shock, National Research Council.

2 "Percent W/V" refers to the weight of substance in grams (W), dissolved in volume of $100 \mathrm{ml}$ of solution $(\mathrm{V})$

3 Figures in brackets indicate the literature references at the end of this paper.
}

Procurement Agency during the past 2 years. Samples acquired in 1953 are listed separately to provide data on the product then in production. Although the commercial products are now fairly uniform, the development work still in progress may lead to products having properties slightly different from those now considered typical of the commercial product. The factors investigated and the results obtained are given in the following sections.

\section{Preparation of the Samples for Analysis}

The samples of clinical dextran received in powderad form were dissolved in water, filtered, and lyophilized (freeze-dried). Dextran received in clinical solution was separated for study in the following manner: The 6-percent solution containing sodium chloride was forced in a fine stream into 7 volumes of methanol, which was constantly stirred. The transfer of the dextran solution was effected by air pressure, using a wash-bottle type of apparatus. The precipitated dextran was separated by filtration and was washed with methanol. The material was then dissolved in water, and the methanol precipitation was repeated. The product was again dissolved in water and lyophilized. For analytical measurements the samples were placed in tared flasks and dried to constant weight under vacuum (less than $0.1 \mathrm{~mm} \mathrm{Hg}$ ). After the dry weight was obtained a 
measured volume of water was added from a pipet, and the flask containing the solution was weighed. The density of each solution was determined by means of a calibrated picnometer.

\section{Optical Rotation}

\subsection{Apparatus}

Two quartz-wedge saccharimeters, Bates type, [3] with adjustable sensitivity were used in the measurements of optical rotation for white light. The light source was a 100-watt, concentratedfilament electric lamp with a filter $15 \mathrm{~mm}$ thick containing 6-percent potassium dichromate solution. The instruments were located in constant-temperature rooms held at $20^{\circ} \pm 1^{\circ} \mathrm{C}$. By circulation of water through the jackets of the polariscope tubes the temperature of the solutions under observation was maintained at $20^{\circ} \pm 0.02^{\circ} \mathrm{C}$.

The rotations for sodium light were made on a $400-\mathrm{mm}$ polarimeter illuminated by a sodium are of American manufacture. The light was filtered through the dichromate filter. The spectral characteristics of this light source have been reported [4]. This polarimeter was adjacent to one of the saccharimeters and arranged so that observations could be made on both instruments with a minimum of handling and without interrupting the flow of water through the jacket of the tube.

Measurements with mercury light, $\lambda=5461$ A were made with a large Schmidt \& Haensch precision polarimeter located in a constant-temperature cabinet maintained at $20^{\circ} \pm 1^{\circ} \mathrm{C}$. This polarimeter was fitted with an air bath, 60 by 40 by $55 \mathrm{~cm}$, placed between the polarizing and analyzing systems and mounted on separate supports to eliminate the possibility of disturbing the adjustments of the polarimeter by the opening and closing of the door. The trough of the instrument passed through the end walls of the air tbermostat without touching them. The temperature of the air bath was thermostatically controlled at $20^{\circ} \pm 0.05^{\circ} \mathrm{C}$. Spectrally purified light having a wavelength of $\lambda=5461 \mathrm{~A}$ was obtained from a mercury-vapor lamp.

\subsection{Polarization}

The solutions for polarization, prepared on a weight basis as described above, were placed in water-jacketed $200-\mathrm{mm}$ tubes. The rotation of each solution was measured by one observer on one of the saccharimeters and by another observer on a second saccharimeter. Upon completion of the saccharimetric observations, the tube was transferred to the polarimeter illuminated by a sodium are and the rotation for sodium light was measured. The tube was then transferred to the precision polarimeter and the optical rotation was measured with the mercury green line $(\lambda=5461$ A). During each series of measurements, standard quartz control plates of known rotation were read on the different instruments to determine the accuracy of the observed readings of the instrument scales. In practically all cases the required scale corrections were small.

\subsection{Calculation of Specific Rotations}

The specific rotations were calculated by the equation:

$$
[\alpha]_{\lambda}^{t}=\frac{100 \alpha}{p d l} \text { or } \frac{100 \alpha}{c l}
$$

where $\alpha$ is the observed rotation in circular degrees; $d$, the density; $l$, the length of the tube in decimeters; $p$, the grams of substance in $100 \mathrm{~g}$ of solution, and $c$ is the grams per $100 \mathrm{ml}$ of solution.

Conversion factors: In order to calculate specific rotations from saccharimeter readings in sugar degrees $\left({ }^{\circ} \mathrm{S}\right)$ it is necessary to convert the readings to their equivalent in circular degrees for a specific wavelength. The factor 0.34620 is ordinarily employed to convert readings in ${ }^{\circ} \mathrm{S}$ on the saccharimeter illuminated with white light and the dichromate filter to the equivalent in circular degrees for sodium light of wavelength, $\lambda=5893 \mathrm{~A}$. This conversion factor was determined by Bates and Jackson [5] for the ratio of the rotation of the normal quartz plate in sugar degrees to its rotation in circular degrees for sodium light. The corresponding ratio for a normal sugar solution was found by them to be 0.34617 . These factors are applicable to all substances having approximately the same rotatory dispersion as quartz or sucrose. To establish the suitability of the coversion factor 0.34620 for use with dextran solutions, the ratio $\alpha_{5893 \mathrm{~A}}^{20} /{ }^{\circ} \mathrm{S}_{20^{\circ} \mathrm{C}}$ was calculated from the optical-rotation data, comprising 21 determinations, on a series of samples of domestic manufacture. The results are given in table 1 . The average value of $\alpha_{5893 \mathrm{~A}}^{20^{\circ} \mathrm{C}}{ }^{\circ} \mathrm{S} \mathrm{S}_{20^{\circ} \mathrm{C}}$ was found to be 0.34617 , in good agreement with the conventional value of 0.34620 . The values of $\alpha_{5461 \mathrm{~A}}^{20^{\circ} \mathrm{C}} /{ }^{\circ} \mathrm{S}_{20^{\circ} \mathrm{C}}$ and $\alpha_{5893 \mathrm{~A}}^{20^{\circ} \mathrm{C}}$ $\alpha_{5461 \mathrm{~A}}^{20^{\circ} \mathrm{C}}$ for dextran were found to be 0.40916 and 0.84599 , respectively, in comparison with the previously determined values of 0.40690 and 0.85085 for quartz, and 0.40763 and 0.84922 for sucrose. The differences in the corresponding ratios are caused by differences in the rotatory dispersions of dextran, quartz, and sucrose. The difference in the dispersion of dextran solutions and that of quartz makes the photometric field for a dextran solution in a saccharimeter appreciably heterochromatic. Hence, one must match an intensity of one color by a supposedly equal intensity of slightly different color.

$$
\text { TABLE 1. Factors for comparing optical-rotation measure- }
$$

\begin{tabular}{|c|c|c|c|c|}
\hline Material & Observers & $\frac{\alpha_{5893 \mathrm{~A}}^{20^{\circ} \mathrm{C}}}{{ }^{\circ} \mathrm{S}_{20^{\circ} \mathrm{C}}}$ & $\frac{\alpha_{5461 \mathrm{~A}}^{20^{\circ} \mathrm{C}}}{{ }^{\circ} \mathrm{S}_{20^{\circ} \mathrm{C}}}$ & $\begin{array}{c}\alpha_{5893 \mathrm{~A}}^{20^{\circ} \mathrm{C}} \\
\alpha_{5461 \mathrm{~A}}^{20^{\circ} \mathrm{C}}\end{array}$ \\
\hline $\begin{array}{l}\text { Quartz plate } \\
\text { Do } \\
\text { Sucrose } \\
\text { Dextran B512 } \\
\text { Dextran (strains other } \\
\text { than B512). }\end{array}$ & $\begin{array}{l}\text { Bates and Jackson } \\
\text { Present } \\
\text { Bates and Jackson } \\
\text { Present }\end{array}$ & $\begin{array}{r}0.34620 \\
.34621 \\
.34617 \\
.34617 \\
.34663\end{array}$ & $\begin{array}{r}0.40690 \\
.40687 \\
.40763 \\
.40916 \\
.40927\end{array}$ & $\begin{array}{r}0.85085 \\
.85091 \\
.84922 \\
.84599 \\
.84708\end{array}$ \\
\hline
\end{tabular}
ments made with different light sources 
The complication, however, does not seem to cause large errors; thus the reproducibility of the specific rotations with the saccharimeter was $\pm 0.14^{\circ}$, with the polarimeter and sodium light $\pm 0.18^{\circ}$, and with the polarimeter and the mercury green light $\pm 0.10^{\circ}$, These results show that there is no appreciable advantage with respect to precision in the use of the polarimeter over the saccharimeter or of the mercury green line over the sodium line.

The specific rotations determined on representative samples from various sources are assembled in tables 2 and 3 . The sample listed as number 1 of table 2 was selected from a group representing 20 lots of clinical dextran obtained early in 1951 from a domestic manufacturer because it showed the lowest specific rotation. Numbers 2 and 3 are typical of the product supplied by this firm in the spring of 1951; number 4 represents a more recent shipment (May 1952). Number 5 gives the rotations of one of the first products submitted to us by another American manufacturer. There is no information concerning the strain of bacteria used in its preparation. Numbers 6, 7, 8, 16, and 18 are typical of the early domestic products. Samples 9, 10, 11, and 12 were shipments obtained from abroad in the spring of 1951. The reason for the wide difference in 11 and 12 is not known. Subsequently, samples 13 and 14 were supplied by one of the British producers; they were produced early and may not represent the current product of this concern. Sample 15 is not a commercial product; it was prepared at the Northern Utilization Research Branch for experimental purposes.

TABLE 2. Optical rotations of dextrans obtained from various sources in 1951 and 1952

\begin{tabular}{|c|c|c|c|c|c|c|}
\hline \multirow{2}{*}{\multicolumn{3}{|c|}{ Sample }} & \multicolumn{4}{|c|}{ Specific rotations } \\
\hline & & & \multicolumn{2}{|c|}{ Saccharimetric a } & \multicolumn{2}{|c|}{ Polarimetric b } \\
\hline $\begin{array}{c}\text { Num- } \\
\text { ber }\end{array}$ & Designation & $\begin{array}{l}\text { Bacterial } \\
\text { strain }\end{array}$ & {$[\alpha]_{5893 \mathrm{~A}}^{20 \mathrm{O}^{\circ} \mathrm{C}}$} & {$[\alpha]_{5461 \mathrm{~A}}^{20{ }^{\circ} \mathrm{C}}$} & {$[\alpha]_{5893 \mathrm{~A}}^{20{ }^{\circ} \mathrm{C}}$} & {$[\alpha]_{5461 \mathrm{~A}}^{20{ }^{\circ} \mathrm{C}}$} \\
\hline \begin{tabular}{l|}
1 \\
$2 \ldots$ \\
$2-\ldots$ \\
$3 . \ldots$
\end{tabular} & $\begin{array}{l}84668 \\
84657 \\
84649 \\
258 \mathrm{~S} 1 \\
\end{array}$ & $\begin{array}{l}\text { B512 } \\
\text { B512 } \\
\text { B512 } \\
\text { B512 }\end{array}$ & $\begin{array}{l}196.10 \\
199.10 \\
199.12 \\
197.66\end{array}$ & $\begin{array}{l}231.89 \\
235.68 \\
235.32 \\
233.60\end{array}$ & $\begin{array}{l}\text { 196. } 10 \\
199.10 \\
199.37 \\
197.77\end{array}$ & $\begin{array}{l}232.12 \\
235.52 \\
235.53 \\
233.79\end{array}$ \\
\hline $\begin{array}{l}5 \ldots \\
6 \ldots-\end{array}$ & $\begin{array}{l}\mathrm{R}-2 \\
\mathrm{R}-7\end{array}$ & B 512 & $\begin{array}{l}201.23 \\
196.71\end{array}$ & $\begin{array}{l}237.82 \\
232.49\end{array}$ & $\begin{array}{l}201.83 \\
196.55\end{array}$ & $\begin{array}{l}237.89 \\
232.40\end{array}$ \\
\hline $7 \ldots$ & $\begin{array}{c}253-\mathrm{P} 9-11- \\
\text { RD-85. }\end{array}$ & B512 & 197.89 & 233.88 & 197. 76 & 233.84 \\
\hline $\begin{array}{l}16 \\
17^{\mathrm{c}}\end{array}$ & $\begin{array}{c}\text { J-2 } \\
\text { Hydro-12- } \\
\text { RD-65. }\end{array}$ & B512 & $\begin{array}{l}196.17 \\
197.74\end{array}$ & $\begin{array}{l}231.85 \\
233.70\end{array}$ & $\begin{array}{l}196.42 \\
197.71\end{array}$ & $\begin{array}{l}231.98 \\
233.83\end{array}$ \\
\hline $\begin{array}{l}8-.- \\
18-\end{array}$ & L $\mathrm{L}-1 \ldots$ & $\begin{array}{l}\text { B512 } \\
\text { B512 }\end{array}$ & $\begin{array}{l}\text { 199. } 36 \\
198.41\end{array}$ & $\begin{array}{l}235.64 \\
234.52\end{array}$ & $\begin{array}{l}\text { 200. } 28 \\
198.76\end{array}$ & $\begin{array}{l}236.26 \\
234.38\end{array}$ \\
\hline $\begin{array}{l}9-\ldots \\
10-\end{array}$ & $163 \ldots$ & $\begin{array}{l}\text { Swedish... } \\
\text { Swedish... }\end{array}$ & $\begin{array}{l}204.48 \\
204.79\end{array}$ & $\begin{array}{l}241.66 \\
242.04\end{array}$ & $\begin{array}{l}204.79 \\
204.75\end{array}$ & $\begin{array}{l}242.49 \\
241.02\end{array}$ \\
\hline $\begin{array}{l}11-. \\
12-\end{array}$ & 50074 & $?$ & $\begin{array}{l}210.00 \\
194.59\end{array}$ & $\begin{array}{l}248.10 \\
229.97\end{array}$ & $\begin{array}{l}210.34 \\
194.74\end{array}$ & $\begin{array}{l}248.27 \\
230.20\end{array}$ \\
\hline $13 \ldots$ & 51103 & $\begin{array}{c}\text { Birming- } \\
\text { ham. }\end{array}$ & 209.25 & 247.29 & 208. 22 & 246.84 \\
\hline 14 & $51215_{-}$ & B512.. & 199. 05 & 235.25 & 199.07 & 234. 91 \\
\hline 15 & 3651.47 & B742 & 210.97 & 249.33 & 211.05 & 249. 08 \\
\hline
\end{tabular}

a Calculated from saccharimeter readings and conversion factors 0.34620 and 0.40916 , respectively.

$\mathrm{b}$ Calculated from polarimeter readings for wavelengths $\lambda=5893 \mathrm{~A}$ and $\lambda=5461 \mathrm{~A}$, respectively.

- Dextran modified by hydrogenation.
The samples listed in table 3 were supplied by the Engineering Development Division, Armed Services Medical Procurement Agency. They are considered typical of current domestic clinical dextran.

The number-average molecular weights of many of the samples of clinical dextran listed in table 2 were determined by several methods and are reported in an earlier publication [6]. Values for the samples of table 3 were measured by the Somogyi phosphate method, using gentiobiose as a standard and are given in table 4 .

TABLE 3. Optical rotations of dextrans obtained from domestic manufacturers in 1953

\begin{tabular}{|c|c|c|c|c|c|c|}
\hline \multirow{2}{*}{\multicolumn{3}{|c|}{ Sample }} & \multicolumn{4}{|c|}{ Specific rotations } \\
\hline & & & \multicolumn{2}{|c|}{ Saccharimetric a } & \multicolumn{2}{|c|}{ Polarimetric b } \\
\hline $\begin{array}{l}\text { Num- } \\
\text { ber }\end{array}$ & Designation & $\begin{array}{l}\text { Bacterial } \\
\text { strain }\end{array}$ & {$[\alpha]_{5893 \mathrm{~A}}^{20^{\circ} \mathrm{C}}$} & {$[\alpha]_{5461 \mathrm{~A}}^{20^{\circ} \mathrm{C}}$} & {$[\alpha]_{5893 \mathrm{~A}}^{20{ }^{\circ} \mathrm{C}}$} & {$[\alpha]_{5461 \mathrm{~A}}^{200^{\circ} \mathrm{C}}$} \\
\hline 19. & 268R5B & B512. & 198. 59 & 234.70 & 198. 26 & 234.64 \\
\hline 20 & $269 \times 2 \mathrm{~A}$ & B512. & 198.07 & 234.09 & 198.04 & 234. 29 \\
\hline $21 \ldots$ & $273 \mathrm{RIC}_{-}$ & B512. & 198.06 & 234.08 & 198.04 & 234.21 \\
\hline 22 & EX510 & B512. & 198.02 & 234.04 & 197.84 & 234.20 \\
\hline $23 \ldots$ & EX509_. & B512 & 197.15 & 233.00 & 196.91 & 233. 78 \\
\hline 24 & EX518... & B512 & 197.47 & 233. 38 & 197.23 & 233.48 \\
\hline 25 & $\begin{array}{l}271 \mathrm{H} 2: \\
5123 \mathrm{~B}\end{array}$ & B512_ & 199.17 & 235.40 & 199.45 & 235. 76 \\
\hline 26 & $\begin{array}{l}273 \mathrm{~A} 3: \ldots \ldots \\
5220 \mathrm{~A}\end{array}$ & B512. & 199.68 & 235.99 & 199. 93 & 236.00 \\
\hline 27. & $\begin{array}{r}273 \mathrm{~S} 5 \mathrm{:} \\
5254 \mathrm{~B}\end{array}$ & B512 . & 199.66 & 235.97 & 199.93 & 236. 10 \\
\hline 28 & $03101 \mathrm{~B}$ & B512_ & 199. 70 & 236.01 & 199.65 & 235.92 \\
\hline 29. & 01002 & B512. & 198.67 & 234.80 & 198.48 & 234.63 \\
\hline $30 \ldots$ & $02601 \mathrm{~B}$. & B512 . & 199.00 & 235.19 & 199. 14 & 235.05 \\
\hline
\end{tabular}

a Calculated from saccharimeter readings and conversion factors 0.34620 and 0.40916 , respectively.

$\mathrm{b}$ Calculated from polarimeter readings for wavelengths $\lambda=5893 \mathrm{~A}$ and $\lambda=5461 \mathrm{~A}$, respectively.

TABLE 4. Number-average molecular weights of dextrans

\begin{tabular}{|c|c|c|c|}
\hline Sample & $\begin{array}{l}\text { Number- } \\
\text { average } \\
\text { molecular } \\
\text { weights }\end{array}$ & Sample & $\begin{array}{l}\text { Number- } \\
\text { a verage } \\
\text { molecular } \\
\text { weights }\end{array}$ \\
\hline $\begin{array}{l}19 \\
20 \\
21 \\
22 \\
23\end{array}$ & $\begin{array}{l}44,600 \\
49,300 \\
46,000 \\
43,300 \\
51,700 \\
54,900\end{array}$ & $\begin{array}{l}25 \\
26 \\
27 \\
28 \\
29 \\
30\end{array}$ & $\begin{array}{l}37,100 \\
41,700 \\
38,400 \\
58,700 \\
35,000 \\
50,900\end{array}$ \\
\hline
\end{tabular}

\subsection{Effect of Concentration on the Specific Rotation of Aqueous Dextran}

To determine the effect of concentration on the specific rotation of dextran, a quantity of lyophilized dextran was transferred to a carefully calibrated $100-\mathrm{ml}$ volumetric flask. The material in the flask was dried in the usual manner and its exact weight obtained. The material was then dissolved in water and made to volume at $20^{\circ} \mathrm{C}$ and weighed. This solution, containing 10.507 percent by weight of dextran, was then measured on the saccharimeter with white light and on the polarimeters with sodium. light and mercury green light. Weighed portions of this solution were transferred to volumetric flasks, and solutions containing about 8, 4, and 2 
TABLE 5. Optical rotations of a sample of dextran at different concentrations at $20^{\circ} \mathrm{C}$

\begin{tabular}{|c|c|c|c|c|c|c|c|c|}
\hline \multirow{3}{*}{ Concentration } & \multicolumn{8}{|c|}{ Specific rotations } \\
\hline & \multicolumn{4}{|c|}{ Saccharimetric } & \multicolumn{4}{|c|}{ Polarimetric } \\
\hline & {$[\alpha]_{5893 \mathrm{~A}}^{20{ }^{\circ} \mathrm{C}}$} & $\begin{array}{l}\text { Deviation } \\
\text { from } \\
\text { average }\end{array}$ & {$[\alpha]_{5461 \mathrm{~A}}^{20 \circ \mathrm{C}}$} & $\begin{array}{l}\text { Deviation } \\
\text { from } \\
\text { average }\end{array}$ & {$[\alpha]_{5893}^{200^{\circ} \mathrm{C}}$} & $\begin{array}{l}\text { Deviation } \\
\text { from } \\
\text { average }\end{array}$ & {$[\alpha]_{5461 \mathrm{~A}}^{20^{\circ} \mathrm{C}}$} & $\begin{array}{l}\text { Deviation } \\
\text { from } \\
\text { average }\end{array}$ \\
\hline $\begin{array}{l}\quad g / 100 \mathrm{ml} \\
10.935 \ldots \ldots \\
8.327 \\
4.531 \\
2.042\end{array}$ & $\begin{array}{l}200.07 \\
199.99 \\
200.03 \\
199.74\end{array}$ & $\begin{array}{r}+0.13 \\
+.05 \\
+.09 \\
-.20\end{array}$ & $\begin{array}{l}236.46 \\
236.36 \\
236.42 \\
236.05\end{array}$ & $\begin{array}{r}+0.14 \\
+.04 \\
+.10 \\
-.27\end{array}$ & $\begin{array}{l}200.02 \\
199.93 \\
200.10 \\
199.54\end{array}$ & $\begin{array}{r}+0.12 \\
+.03 \\
+.20 \\
-.36\end{array}$ & $\begin{array}{l}236.31 \\
236.16 \\
236.48 \\
236.40\end{array}$ & $\begin{array}{r}-0.03 \\
-.18 \\
+.14 \\
+.06\end{array}$ \\
\hline Average. . & 199.94 & \pm 0.12 & 236.32 & \pm 0.14 & 199. 90 & \pm 0.18 & 236.34 & \pm 0.10 \\
\hline
\end{tabular}

percent were prepared. The results given in table 5 show that there is no significant change in specific rotation with a change in concentration from 10 to $3 \mathrm{~g} / 100 \mathrm{ml} .^{4}$

\subsection{Effect of Temperature on the Specific Rotation of Dextran}

To provide information as to the variation of the specific rotation of dextran with temperature, the measurements given in table 6 were conducted. In each measurement the temperature of the solution was controlled by circulating water from a thermostat; the temperature of the instrument was maintained at or near that of the solution by adjustment of the temperature of the room to the desired point. In the calculations of specific rotation a correction was made for the change in volume of the solution due to expansion or contraction. The thermal expansion coefficient $\left(0.00022 /^{\circ} \mathrm{C}\right)$ of a 6-percent dextran solution was determined in a separate experiment. The results may be expressed by the equation

$$
[\alpha]_{5893 \mathrm{~A}}^{20^{\circ} \mathrm{C}}=[\alpha]_{5893 \mathrm{~A}}^{t}(1+0.00033(t-20)),
$$

where $[\alpha]_{5893 \mathrm{~A}}^{t}$ is the specific rotation at the temperature $t\left(t=15^{\circ}\right.$ to $\left.30^{\circ} \mathrm{C}\right)$.

TABLE 6. Specific optical rotations of a dextran solution at different temperatures

\begin{tabular}{|c|c||c|c|}
\hline Temperature ${ }^{\circ} \mathrm{C}$ & {$[\alpha]_{5893 \mathrm{~A}}^{t}$} & Temperature ${ }^{\circ} \mathrm{C}$ & {$[\alpha]_{5993 \mathrm{~A}}^{t}$} \\
\hline & $\begin{array}{r}+199.27 \\
199.00\end{array}$ & 25 & 198.70 \\
\hline 15 & 30 & 198.29 \\
\hline
\end{tabular}

\subsection{Effect of the Presence of Sodium Chloride on the Optical Rotation of Dextran}

Solutions of dextran for clinical use ordinarily contain 0.9 percent $\mathrm{W} / \mathrm{V}$ of sodium chloride. To ascertain whether the salt alters the optical rotation appreciably, measurements were made on two

${ }_{4}$ This is in agreement with the findings of the Commercial Solvents Corp. furnished in a private communication. samples, comparing the specific rotation in water solution with that obtained in the presence of salt. The differences (see table 7 ) are of the order of the average deviation in the values obtained for measurements either in water or in salt solution.

TABLE 7. Effect of sodium chloride on the specific rotation of dextran solutions

\begin{tabular}{|c|c|c|c|c|c|c|}
\hline \multirow{3}{*}{ Sample } & \multicolumn{6}{|c|}{ Specific rotations } \\
\hline & \multicolumn{2}{|c|}{ Salt-free } & \multicolumn{2}{|c|}{$0.9 \% \mathrm{~W} / \mathrm{V}$ of $\mathrm{NaCl}$} & \multicolumn{2}{|c|}{$0.98 \% \mathrm{~W} / \mathrm{V}$ of $\mathrm{NaC}$} \\
\hline & {$[\alpha]_{5893 \mathrm{~A}}^{20{ }^{\circ} \mathrm{C}}$} & {$[\alpha]_{5431 \mathrm{~A}}^{20{ }^{\circ} \mathrm{C}}$} & {$[\alpha]_{5893 \mathrm{~A}}^{20 \mathrm{C}^{\circ} \mathrm{C}}$} & {$[\alpha]_{5+51}^{200 \mathrm{C}}$} & {$[\alpha]_{5893 \mathrm{~A}}^{200 \mathrm{C}}$} & {$[\alpha]_{5461 \mathrm{~A}}^{20{ }^{\circ} \mathrm{C}}$} \\
\hline $258 \mathrm{~S} 1 \ldots$ & 197. 72 & 233. 79 & 197. 62 & 233.74 & -....- & -..... \\
\hline$J-1 \ldots$ & 197.83 & 233.84 & 198. 09 & 234.01 & 197.63 & 233.97 \\
\hline
\end{tabular}

\subsection{Effect of Methanol on the Optical Rotation of Dextran in Water}

In the manufacture and in the evaluation of clinical dextran it is sometimes necessary to determine the concentration of the material in mixtures containing known volumes of water and methanol. To provide a basis for the polarimetric determination of dextran in mixtures of water and methanol, the specific rotation of a typical dextran was determined for various concentrations of methanol in water. The results given in table 8 show that the optical rotations in a 40:60 mixture of methanol and water are about 1 percent higher than those obtained in water alone.

TABLE 8. Specific rotation of dextran in aqueous methanol at $20^{\circ} \mathrm{C}$

\begin{tabular}{|c|c|c|c|}
\hline \multicolumn{2}{|c|}{ Solvent } & \multicolumn{2}{|c|}{ Specific rotation } \\
\hline $\begin{array}{l}\text { Volume of } \\
\text { methanol }\end{array}$ & $\begin{array}{l}\text { Volume of } \\
\text { water }\end{array}$ & {$[\alpha]_{5893 \mathrm{~A}}^{20 \circ \mathrm{C}}$} & {$[\alpha]_{5461 \mathrm{~A}}^{20{ }^{\circ} \mathrm{C}}$} \\
\hline $\begin{array}{r}0 \\
10 \\
20 \\
30 \\
40\end{array}$ & $\begin{array}{r}100 \\
90 \\
80 \\
70 \\
60\end{array}$ & $\begin{array}{l}199.15 \\
198.98 \\
199.83 \\
199.95 \\
201.00\end{array}$ & $\begin{array}{l}235.45 \\
235.61 \\
236.13 \\
236.55 \\
237.39\end{array}$ \\
\hline
\end{tabular}




\section{Refractive Indices of Dextran Solutions}

\subsection{Aqueous Solutions}

The refractive indices of dextran solutions were determined by means of a carefully calibrated precision refractometer, using a sodium arc light. The measurements were made in a constant-temperature room maintained at $20^{\circ} \pm 1^{\circ} \mathrm{C}$. Water from a water thermostat was circulated through the water-jacketed prisms of the instrument, holding the temperature at $20^{\circ} \pm 0.01^{\circ} \mathrm{C}$. At the beginning and end of each series of readings a sample of distilled water was read as a control. The scale corrections for the instrument were applied to the observed readings. In the range covered they did not exceed a value corresponding to one in the fifth decimal place of the index.

The entire series of solutions used in the opticalrotation measurements of table 2 were measured in the refractometer. As these were all either approximately 3 percent or 6 percent, additional solutions were prepared in like manner for the remaining concentrations measured. In all, 43 solutions were employed, of which all but 11 were prepared from clinical dextran from the Commercial Solvents Corp. Computation of the relationship of the refractive index to the percentage of dextran by the method of averages gave the equation

$$
n_{D}^{20}=1.33299+0.00151005 p+0.000006372 p^{2},
$$

where $p$ is the number of grams of dextran in $100 \mathrm{~g}$ of solution (weights in air). ${ }^{5}$ The experimentally determined indices and the deviations from the equation are given in table 9 . The results show no consistent difference in the refractive indices of dextrans from different sources.

\subsection{Aqueous Sodium Chloride Solutions}

The refractive indices of dextran dissolved in 0.9 percent $\mathrm{W} / \mathrm{V}$ of sodium chloride were measured in the manner described above at 20 concentrations.

In a similar manner the indices of dextran in 0.3 percent $\mathrm{W} / \mathrm{V}$ of sodium chloride were measured at 12 concentrations.

From the data obtained, the following equations relating the grams of dextran in $100 \mathrm{ml}$ of solution containing sodium chloride and refractive index were obtained by the method of averages:

$$
\begin{aligned}
& n_{D}^{20^{\circ} \mathrm{C}}(\text { in } 0.9 \text { percent } \mathrm{W} / \mathrm{V} \text { of } \mathrm{NaCl})= \\
& 1.33455+0.0015162 C-0.00000319 C^{2},
\end{aligned}
$$

where $C$ equals 0 to $9 \mathrm{~g}$ of dextran in $100 \mathrm{ml}$ of 0.3 percent $\mathrm{W} / \mathrm{V}$ of $\mathrm{NaCl}$.

$$
\begin{aligned}
& n_{D}^{20^{\circ} \mathrm{C}}(\text { in } 0.3 \text { percent } \mathrm{W} / \mathrm{V} \text { of } \mathrm{NaCl})= \\
& 1.33352+0.0015148 C-0.000000754 C^{2},
\end{aligned}
$$

\begin{tabular}{|c|c|c|c|c|c|c|c|}
\hline $\begin{array}{l}\text { Weight } \\
\text { (in :ir) }\end{array}$ & $\begin{array}{c}\text { Observed } \\
n_{D}^{20^{\circ} \mathrm{C}}\end{array}$ & $\begin{array}{c}\text { Calculated } \\
n_{D}^{20}{ }^{\circ} \mathrm{C}\end{array}$ & $\begin{array}{l}\text { Differ- } \\
\text { ence a }\end{array}$ & $\begin{array}{l}\text { Weight } \\
\text { (in air) }\end{array}$ & $\begin{array}{c}\text { Observed } \\
n_{D}^{20^{\circ} \mathrm{C}}\end{array}$ & $\begin{array}{c}\text { Calculated } \\
n_{D}^{20^{\circ} \mathrm{C}}\end{array}$ & $\begin{array}{l}\text { Differ- } \\
\text { ence a }\end{array}$ \\
\hline$\%$ & & & $\times 10^{-5}$ & $\%$ & & & $\times 10^{-5}$ \\
\hline $\begin{array}{l}0.501 \\
1.003 \\
1.102 \\
1.318 \\
1.516\end{array}$ & $\begin{array}{l}\text { 1. } 33375 \\
\text { 1. } 33451 \\
\text { 1. } 33459 \\
\text { 1. } 33498 \\
1.33525\end{array}$ & $\begin{array}{l}\text { 1. } 33375 \\
\text { 1. } 33451 \\
\text { 1. } 33466 \\
\text { 1. } 33499 \\
\text { 1. } 33529\end{array}$ & $\begin{array}{r}0 \\
0 \\
+7 \\
+1 \\
+4\end{array}$ & $\begin{array}{l}\text { 3. } 020 \\
\text { 3. } 022 \\
\text { 3. } 025 \\
\text { 3. } 054\end{array}$ & $\begin{array}{l}\text { 1. } 33761 \\
\text { 1. } 33755 \\
\text { 1. } 33766 \\
\text { 1. } 33771\end{array}$ & $\begin{array}{l}\text { 1. } 33761 \\
\text { 1. } 33761 \\
\text { 1. } 33762 \\
\text { 1. } 33766\end{array}$ & $\begin{array}{r}0 \\
+6 \\
-4 \\
-5\end{array}$ \\
\hline $\begin{array}{l}1.828 \\
1.866 \\
1.975 \\
2.031 \\
2.572\end{array}$ & $\begin{array}{l}\text { 1. } 33576 \\
\text { 1. } 33583 \\
\text { 1. } 33603 \\
\text { 1. } 33606 \\
\text { 1. } 33691\end{array}$ & $\begin{array}{l}\text { 1. } 33577 \\
1.33583 \\
1.33600 \\
1.33608 \\
1.33692\end{array}$ & $\begin{array}{r}+1 \\
0 \\
-3 \\
+2 \\
+1\end{array}$ & $\begin{array}{l}3.152 \\
3.694 \\
3.956 \\
4.463 \\
5.111\end{array}$ & $\begin{array}{l}\text { 1. } 33788 \\
\text { 1. } 33871 \\
\text { 1. } 33908 \\
\text { 1. } 33988 \\
\text { 1. } 34090\end{array}$ & $\begin{array}{l}\text { 1. } 33781 \\
\text { 1. } 33866 \\
\text { 1. } 33906 \\
\text { 1. } 33986 \\
1.34087\end{array}$ & $\begin{array}{l}-7 \\
-5 \\
-2 \\
-2 \\
-3\end{array}$ \\
\hline $\begin{array}{l}2.572 \\
2.606 \\
2.677 \\
2.883 \\
2.925 \\
2.936\end{array}$ & $\begin{array}{l}\text { 1. } 33091 \\
\text { 1. } 33692 \\
\text { 1. } 33709 \\
\text { 1. } 33735 \\
\text { 1. } 33744 \\
1.33760\end{array}$ & $\begin{array}{l}\text { 1. } 33092 \\
\text { 1. } 33697 \\
\text { 1. } 33708 \\
\text { 1. } 33740 \\
\text { 1. } 33746 \\
1.33748\end{array}$ & $\begin{array}{l}+1 \\
+5 \\
-1 \\
+5 \\
+2 \\
-12\end{array}$ & $\begin{array}{l}5.386 \\
5.598 \\
5.613 \\
5.620 \\
5.641\end{array}$ & $\begin{array}{l}1.34129 \\
\text { 1. } 34168 \\
\text { 1. } 34164 \\
\text { 1. } 34167 \\
\text { 1. } 34166\end{array}$ & $\begin{array}{l}1.34131 \\
1.34164 \\
1.34167 \\
1.34168 \\
1.34171\end{array}$ & $\begin{array}{l}+2 \\
-4 \\
+3 \\
+1 \\
+5\end{array}$ \\
\hline $\begin{array}{l}2.941 \\
2.946 \\
2.955 \\
2.980 \\
2.989\end{array}$ & $\begin{array}{l}\text { 1. } 33756 \\
\text { 1. } 33743 \\
\text { 1. } 33749 \\
\text { 1. } 33759 \\
\text { 1. } 33760\end{array}$ & $\begin{array}{l}\text { 1. } 33749 \\
\text { 1. } 33749 \\
1.33751 \\
\text { 1. } 33755 \\
1.33756\end{array}$ & $\begin{array}{l}-7 \\
+6 \\
+2 \\
-4 \\
-4\end{array}$ & $\begin{array}{l}5.664 \\
5.723 \\
5.912 \\
5.950 \\
6.079\end{array}$ & $\begin{array}{l}\text { 1. } 34171 \\
\text { 1. } 34183 \\
\text { 1. } 34203 \\
\text { 1. } 34215 \\
\text { 1. } 34236\end{array}$ & $\begin{array}{l}\text { 1. } 34175 \\
\text { 1. } 34184 \\
\text { 1. } 34214 \\
\text { 1. } 34220 \\
\text { 1. } 34241\end{array}$ & $\begin{array}{r}+4 \\
+1 \\
+11 \\
+5 \\
+5\end{array}$ \\
\hline 2. 989 & 1. 33760 & 1. 33756 & -4 & $\begin{array}{r}7.355 \\
8.082 \\
10.507\end{array}$ & $\begin{array}{l}\text { 1. } 34453 \\
\text { 1. } 34564 \\
\text { 1. } 34954\end{array}$ & $\begin{array}{l}\text { 1. } 34444 \\
\text { 1. } 34561 \\
1.34956\end{array}$ & $\begin{array}{l}-9 \\
-3 \\
+2\end{array}$ \\
\hline
\end{tabular}

5 Subsequently, an equation was derived by the method of least squares, which yielded essentially the same values as those obtained with eq (3), showing the adequacy of the accepted treatment of the data.

TABLE 9. Refractive indices of aqueous solutions of dextran at $20^{\circ} \mathrm{C}$

- Calculated minus observed. 
TABLE 10. Data on refractive indices of dextran in sodium-chloride solutions at $20^{\circ} \mathrm{C}$ and comparison with interpolation equations

\begin{tabular}{|c|c|c|c|c|c|c|c|}
\hline \multicolumn{4}{|c|}{ Dextran dissolved in $0.9 \% \mathrm{~W} / \mathrm{V}$ of $\mathrm{NaCl}$} & \multicolumn{4}{|c|}{ Dextran dissolved in $0.3 \% \mathrm{~W} / \mathrm{V}$ of $\mathrm{NaCl}$} \\
\hline $\begin{array}{c}\text { Weight in } 100 \\
\text { ml (in air) }\end{array}$ & $\begin{array}{c}\text { Observed } \\
n_{D}^{20^{\circ}} \mathrm{C}\end{array}$ & $\begin{array}{c}\text { Calculated } \\
n_{D}^{20^{\circ} \mathrm{C}}\end{array}$ & $\begin{array}{l}\text { Differ- } \\
\text { ence }^{a}\end{array}$ & $\begin{array}{l}\text { Weight in } 100 \\
\text { ml (in air) }\end{array}$ & $\begin{array}{c}\text { Observed } \\
n_{D}^{20^{\circ}} \mathrm{C}\end{array}$ & $\begin{array}{c}\text { Calculated } \\
n_{D}^{20^{\circ} \mathrm{C}}\end{array}$ & $\begin{array}{l}\text { Differ- } \\
\text { enre }^{a}\end{array}$ \\
\hline $\begin{array}{l}g \\
0.472 \\
.786 \\
\text { 1. } 038 \\
\text { 1. } 125 \\
\text { 1. } 387\end{array}$ & $\begin{array}{l}1.33522 \\
1,33567 \\
1,33362 \\
1.33627 \\
1.33666\end{array}$ & $\begin{array}{l}\text { 1. } 33526 \\
\text { 1. } 33574 \\
1,33612 \\
1.33625 \\
1.33665\end{array}$ & $\begin{array}{c}\times 10-5 \\
+4 \\
+7 \\
0 \\
-2 \\
-1\end{array}$ & $\begin{array}{l}g \\
0.730 \\
\text { 1. } 256 \\
1.835 \\
\text { 2. } 105 \\
2.460\end{array}$ & $\begin{array}{l}\text { 1. } 33465 \\
\text { 1. } 33541 \\
\text { 1. } 33329 \\
\text { 1. } 33671 \\
\text { 1. } 33721\end{array}$ & $\begin{array}{l}\text { 1. } 33463 \\
\text { 1. } 33542 \\
\text { 1. } 336300 \\
\text { 1. } 33671 \\
\text { 1. } 33724\end{array}$ & $\begin{array}{c}\times 10^{-5} \\
-2 \\
+1 \\
+1 \\
0 \\
+3\end{array}$ \\
\hline $\begin{array}{l}1.951 \\
1.970 \\
2.912 \\
3.137 \\
3.243\end{array}$ & $\begin{array}{l}1.33755 \\
1.33749 \\
1.33897 \\
1.33928 \\
1.33946\end{array}$ & $\begin{array}{l}\text { 1. } 33750 \\
\text { 1. } 33752 \\
\text { 1. } 33894 \\
\text { 1. } 33927 \\
\text { 1. } 33943\end{array}$ & $\begin{array}{l}-5 \\
+3 \\
-3 \\
-1 \\
-3\end{array}$ & $\begin{array}{l}3.398 \\
4.182 \\
4.622 \\
5.224 \\
5.351\end{array}$ & $\begin{array}{l}1.33868 \\
1.33984 \\
1.34053 \\
1.34141 \\
1.34162\end{array}$ & $\begin{array}{l}\text { 1. } 33866 \\
\text { 1. } 33984 \\
\text { 1. } 34051 \\
1.34141 \\
1.34160\end{array}$ & $\begin{array}{r}-2 \\
0 \\
-2 \\
0 \\
-2\end{array}$ \\
\hline $\begin{array}{l}\text { 3. } 293 \\
\text { 3. } 480 \\
\text { 3. } 534 \\
\text { 4. } 021 \\
\text { 4. } 504\end{array}$ & $\begin{array}{l}1.33953 \\
1.33976 \\
1.33984 \\
1.34062 \\
1.34129\end{array}$ & $\begin{array}{l}\text { 1. } 33951 \\
\text { 1. } 33979 \\
\text { 1. } 33987 \\
\text { 1. } 34060 \\
\text { 1. } 34131\end{array}$ & $\begin{array}{l}-2 \\
+3 \\
+3 \\
-2 \\
+2\end{array}$ & $\begin{array}{l}5.563 \\
5.798\end{array}$ & $\begin{array}{l}\text { 1. } 34189 \\
\text { 1. } 34226\end{array}$ & $\begin{array}{l}\text { 1. } 34192 \\
\text { 1. } 34226\end{array}$ & $\begin{array}{r}+3 \\
0\end{array}$ \\
\hline $\begin{array}{l}5.098 \\
5.654 \\
5.828 \\
7.108\end{array}$ & $\begin{array}{l}1.34222 \\
1.34301 \\
1.34330 \\
1.34515\end{array}$ & $\begin{array}{l}\text { 1. } 34220 \\
1.34302 \\
1.34328 \\
1.34517\end{array}$ & $\begin{array}{l}-2 \\
+1 \\
-2 \\
+2\end{array}$ & & & & \\
\hline 9. 292 & 1. 34838 & 1.34836 & -2 & & & & \\
\hline
\end{tabular}

a Calculated minus observed.

where $C$ equals 0 to $6 \mathrm{~g}$ of dextran in $100 \mathrm{ml}$ of 0.9 percent $\mathrm{W} / \mathrm{V}$ of $\mathrm{NaCl}$. The experimental and calculated values are given in table 10 .

\section{Densities of Dextran Solutions}

The density values obtained in conjunction with the determinations of specific rotation showed small variations, which seemed to be random errors. Hence a carefully controlled independent series of measurements was made at five concentrations, using separate samples of dextran prepared from strain B512.

The samples were dried and weighed in a calibrated flask having a neck of about $6-\mathrm{mm}$ inside diameter and provided with several graduation marks equally spaced; the volume at each mark was previously ascertained by careful calibration. Above the graduation marks the neck is blown out into a bulb of about 20-ml capacity and the upper end fitted with a ground stopper. The enlargement in the neck permits mixing of the solution by repeated spilling into this bulb without contact with the grinding. When the solution was thoroughly mixed, and with the meniscus within the graduated portion of the neck, the flask and contents were brought to $20^{\circ} \mathrm{C}$ in a thermostated water bath, and the volume was then determined.

From the density data thus obtained, the following equation was calculated by the method of a.verages:

Apparent

$d_{20^{\circ} \mathrm{C}}=0.99717+0.00398133 p+0.00001597 p^{2}$, where $p$ is the number of grams of dextran in $100 \mathrm{~g}$ of solution. The experimental and calculated values of the density are given in table 11. Refractive indices and densities of aqueous solutions of dextran at nominal values of the concentration are given in table 12. The refractive indices of solutions of dextran containing sodium chloride are given in table 13 .

TABLE 11. Data on density of dextran solutions and comparison with interpolation equation

\begin{tabular}{|c|c|c|c|}
\hline $\begin{array}{c}\text { Percentage } \\
\text { of dextran } \\
\text { by weight } \\
\text { (in air) }\end{array}$ & \multicolumn{2}{|c|}{ Apparent density, 20 C } & \\
\cline { 1 - 1 } & Observed & Calculated & \\
11.5242 & 1.04513 & 1.04517 & Residuals a \\
9.0050 & 1.03438 & 1.03432 & +0.00004 \\
6.0189 & 1.02169 & 1.02171 & +.00006 \\
3.0379 & 1.00944 & 1.00941 & -.00002 \\
1.4972 & 1.00314 & 1.00317 & +.00003 \\
\hline
\end{tabular}

a Calculated minus observed.

The authors express their appreciation to the National Research Council, to the Office of the Surgeon General, and to the Engineering Development Division, Armed Services Medical Procurement Agency, for their support and cooperation in this investigation. They are also indebted to the several producers of dextran for providing samples of dextran, analytical methods, and data. The collaboration of S. G. Weissberg and his associates at the Bureau has been most helpful and is gratefully acknowledged. 
TABLE 12. Refractive indices and apparent densities of aqueous olsutions of dextran at $20^{\circ} \mathrm{C}$

\begin{tabular}{|c|c|c|c|}
\hline $\begin{array}{l}\text { Percentage } \\
\text { of dextran } \\
\text { by weight } \\
\text { (in air) }\end{array}$ & $\begin{array}{l}\text { Grams of } \\
\text { dextran } \\
\text { per } 100 \mathrm{ml} \\
\text { (in air) }\end{array}$ & $\begin{array}{l}\text { Apparent } \\
\text { density at } \\
20^{\circ} \mathrm{C} \\
\text { (in air) }\end{array}$ & $\begin{array}{l}\text { Refractive } \\
\text { index, } \\
n_{D}^{20^{\circ} \mathrm{c}}\end{array}$ \\
\hline $\begin{array}{r}0.0 \\
.2 \\
.4 \\
.6 \\
.8\end{array}$ & $\begin{array}{r}0.200 \\
.400 \\
.600 \\
.800\end{array}$ & $\begin{array}{r}0.9972 \\
.9980 \\
.9988 \\
.9996 \\
1.0004\end{array}$ & $\begin{array}{l}1.33299 \\
1.33329 \\
1.33359 \\
1.33390 \\
1.33420\end{array}$ \\
\hline $\begin{array}{l}\text { 1. } 0 \\
\text { 1. } 2 \\
\text { 1. } 4 \\
1.6 \\
1.8\end{array}$ & $\begin{array}{l}\text { 1. } 001 \\
\text { 1. } 202 \\
\text { 1. } 404 \\
\text { 1. } 606 \\
\text { 1. } 808\end{array}$ & $\begin{array}{l}1.0012 \\
1.0020 \\
1.0028 \\
1.0036 \\
1.0044\end{array}$ & $\begin{array}{l}\text { 1. } 33451 \\
\text { 1. } 33481 \\
\text { 1. } 33512 \\
\text { 1. } 33542 \\
\text { 1. } 33573\end{array}$ \\
\hline $\begin{array}{l}2.0 \\
2.2 \\
2.4 \\
2.6 \\
2.8\end{array}$ & $\begin{array}{l}2.010 \\
2.213 \\
2.416 \\
2.620 \\
2.824\end{array}$ & $\begin{array}{l}1.0052 \\
1.0060 \\
1.0068 \\
1.0076 \\
1.0084\end{array}$ & $\begin{array}{l}\text { 1. } 33604 \\
\text { 1. } 33634 \\
\text { 1. } 33665 \\
\text { 1. } 33696 \\
\text { 1. } 33727\end{array}$ \\
\hline $\begin{array}{l}3.0 \\
3.2 \\
3.4 \\
3.6 \\
3.8\end{array}$ & $\begin{array}{l}\text { 3. } 028 \\
\text { 3. } 232 \\
3.437 \\
\text { 3. } 642 \\
3.848\end{array}$ & $\begin{array}{l}1.0093 \\
1.0101 \\
1.0109 \\
1.0117 \\
1.0125\end{array}$ & $\begin{array}{l}\text { 1. } 33758 \\
\text { 1. } 33789 \\
\text { 1. } 33820 \\
\text { 1. } 33851 \\
\text { 1. } 33881\end{array}$ \\
\hline $\begin{array}{l}4.0 \\
4.2 \\
4.4 \\
4.6 \\
4.8\end{array}$ & $\begin{array}{l}\text { 4. } 053 \\
\text { 4. } 260 \\
\text { 4. } 466 \\
\text { 4. } 673 \\
\text { 4. } 880\end{array}$ & $\begin{array}{l}1.0134 \\
1.0142 \\
1.0150 \\
1.0158 \\
1.0167\end{array}$ & $\begin{array}{l}\text { 1. } 33913 \\
\text { 1. } 33944 \\
\text { 1. } 33976 \\
\text { 1. } 34007 \\
\text { 1. } 34038\end{array}$ \\
\hline $\begin{array}{l}5.0 \\
5.2 \\
5.4 \\
5.6 \\
5.8\end{array}$ & $\begin{array}{l}5.087 \\
5.295 \\
5.503 \\
5.712 \\
5.921\end{array}$ & $\begin{array}{l}1.0175 \\
1.0183 \\
1.0191 \\
1.0200 \\
1.0208\end{array}$ & $\begin{array}{l}\text { 1. } 34070 \\
\text { 1. } 34101 \\
\text { 1. } 34133 \\
\text { 1. } 34165 \\
\text { 1. } 34196\end{array}$ \\
\hline $\begin{array}{l}6.0 \\
6.2 \\
6.4 \\
6.6 \\
6.8\end{array}$ & $\begin{array}{l}6.130 \\
6.339 \\
6.549 \\
6.759 \\
6.970\end{array}$ & $\begin{array}{l}\text { 1. } 0216 \\
1.0225 \\
1.0233 \\
1.0241 \\
1.0250\end{array}$ & $\begin{array}{l}\text { 1. } 34228 \\
\text { 1. } 34260 \\
\text { 1. } 34292 \\
\text { 1. } 34323 \\
\text { 1. } 34355\end{array}$ \\
\hline $\begin{array}{l}7.0 \\
7.2 \\
7.4 \\
7.6 \\
7.8\end{array}$ & $\begin{array}{l}\text { 7. } 181 \\
7.392 \\
7.604 \\
7.815 \\
8.028\end{array}$ & $\begin{array}{l}1.0258 \\
1.0267 \\
1.0275 \\
1.0284 \\
1.0292\end{array}$ & $\begin{array}{l}\text { 1. } 34387 \\
\text { 1. } 34419 \\
\text { 1. } 34451 \\
\text { 1. } 34483 \\
\text { 1. } 34516\end{array}$ \\
\hline $\begin{array}{l}8.0 \\
8.2 \\
8.4 \\
8.6 \\
8.8\end{array}$ & $\begin{array}{l}8.240 \\
8.453 \\
8.667 \\
8.880 \\
9.094\end{array}$ & $\begin{array}{l}1.0300 \\
1.0309 \\
1.0317 \\
1.0326 \\
1.0334\end{array}$ & $\begin{array}{l}\text { 1. } 34548 \\
\text { 1. } 34580 \\
\text { 1. } 34612 \\
\text { 1. } 34645 \\
\text { 1. } 34677\end{array}$ \\
\hline $\begin{array}{l}9.0 \\
9.2 \\
9.4 \\
9.6 \\
9.8\end{array}$ & $\begin{array}{r}9.309 \\
9.523 \\
9.738 \\
9.954 \\
10.170\end{array}$ & $\begin{array}{l}1.0343 \\
1.0351 \\
1.0360 \\
1.0369 \\
1.0377\end{array}$ & $\begin{array}{l}\text { 1. } 34710 \\
\text { 1. } 34742 \\
\text { 1. } 34775 \\
\text { 1. } 34807 \\
\text { 1. } 34840\end{array}$ \\
\hline $\begin{array}{l}10.0 \\
10.2 \\
10.4 \\
10.6 \\
10.8\end{array}$ & $\begin{array}{l}\text { 10. } 386 \\
\text { 10. } 602 \\
\text { 10. } 819 \\
11.036 \\
11.254\end{array}$ & $\begin{array}{l}\text { 1. } 0386 \\
\text { 1. } 0394 \\
\text { 1. } 0403 \\
\text { 1. } 0412 \\
1.0420\end{array}$ & $\begin{array}{l}\text { 1. } 34873 \\
\text { 1. } 34906 \\
\text { 1. } 34938 \\
\text { 1. } 34971 \\
\text { 1. } 35004\end{array}$ \\
\hline $\begin{array}{l}11.0 \\
11.2 \\
11.4 \\
11.6 \\
11.8\end{array}$ & $\begin{array}{l}\text { 11. } 472 \\
11.690 \\
11.909 \\
12.128 \\
12.347\end{array}$ & $\begin{array}{l}\text { 1. } 0429 \\
\text { 1. } 0438 \\
\text { 1. } 0446 \\
\text { 1. } 0455 \\
\text { 1. } 0464\end{array}$ & $\begin{array}{l}\text { 1. } 35037 \\
\text { 1. } 35070 \\
\text { 1. } 35103 \\
\text { 1. } 35136 \\
1.35170\end{array}$ \\
\hline 12.0 & 12.567 & 1. 0472 & 1. 35203 \\
\hline
\end{tabular}

TABLE 13. Refractive indices of solutions of dextran containing sodium chloride at $20^{\circ} \dot{C}$

\begin{tabular}{|c|c|c|}
\hline \multirow{2}{*}{$\begin{array}{l}\text { Grams of } \\
\text { dextran } \\
\text { per } 100 \mathrm{ml} \\
\text { (in air) }\end{array}$} & \multicolumn{2}{|c|}{$\begin{array}{l}\text { Refractive index, } n_{D}^{2 v} C \\
\text { of solution containing- }\end{array}$} \\
\hline & $\begin{array}{c}0.3 \% \mathrm{~W} / \mathrm{V} \text { of } \\
\mathrm{NaCl}\end{array}$ & $\begin{array}{c}0.9 \% \mathrm{~W} / \mathrm{V} \text { of } \\
\mathrm{NaCl}\end{array}$ \\
\hline $\begin{array}{l}0.0 \\
.2 \\
.4 \\
.6 \\
.8\end{array}$ & $\begin{array}{l}1.33352 \\
1.33382 \\
\text { 1. } 33412 \\
\text { 1. } 33443 \\
1.33473\end{array}$ & $\begin{array}{l}\text { 1. } 33455 \\
\text { 1. } 33485 \\
\text { 1. } 33515 \\
\text { 1. } 33546 \\
\text { 1. } 33576\end{array}$ \\
\hline $\begin{array}{l}1.0 \\
1.2 \\
1.4 \\
1.6 \\
1.8\end{array}$ & $\begin{array}{l}\text { 1. } 33503 \\
\text { 1. } 33533 \\
\text { 1. } 33564 \\
\text { 1. } 33594 \\
\text { 1. } 33625\end{array}$ & $\begin{array}{l}\text { 1. } 33606 \\
\text { 1. } 33636 \\
\text { 1. } 33666 \\
\text { 1. } 33697 \\
\text { 1. } 33727\end{array}$ \\
\hline $\begin{array}{l}2.0 \\
2.2 \\
2.4 \\
2.6 \\
2.8\end{array}$ & $\begin{array}{l}\text { 1. } 33655 \\
\text { 1. } 33685 \\
\text { 1. } 33715 \\
\text { 1. } 33746 \\
1.33776\end{array}$ & $\begin{array}{l}\text { 1. } 33757 \\
\text { 1. } 33787 \\
\text { 1. } 33817 \\
\text { 1. } 33847 \\
\text { 1. } 33877\end{array}$ \\
\hline $\begin{array}{l}3.0 \\
3.2 \\
3.4 \\
3.6 \\
3.8\end{array}$ & $\begin{array}{l}\text { 1. } 33806 \\
1.33836 \\
1.33866 \\
1.33897 \\
1.33927\end{array}$ & $\begin{array}{l}\text { 1. } 33907 \\
\text { 1. } 33937 \\
\text { 1. } 33967 \\
\text { 1. } 33996 \\
\text { 1. } 34026\end{array}$ \\
\hline $\begin{array}{l}\text { 4. } 0 \\
4.2 \\
4.4 \\
4.6 \\
4.8\end{array}$ & $\begin{array}{l}1.33957 \\
1.33987 \\
1.34017 \\
1.34048 \\
1.34078\end{array}$ & $\begin{array}{l}1.34056 \\
1.34086 \\
1.34116 \\
1.34145 \\
1.34175\end{array}$ \\
\hline $\begin{array}{l}5.0 \\
5.2 \\
5.4 \\
5.6 \\
5.8\end{array}$ & $\begin{array}{l}1.34108 \\
1.34138 \\
1.34168 \\
1.34198 \\
1.34228\end{array}$ & $\begin{array}{l}1.34205 \\
\text { 1. } 34235 \\
\text { 1. } 34264 \\
\text { 1. } 34294 \\
\text { 1. } 34323\end{array}$ \\
\hline $\begin{array}{l}6.0 \\
6.2 \\
6.4 \\
6.6 \\
6.8\end{array}$ & $\begin{array}{c}1.34258 \\
\end{array}$ & $\begin{array}{l}1.34353 \\
1.34383 \\
1.34412 \\
1.34442 \\
1.34471\end{array}$ \\
\hline $\begin{array}{l}7.0 \\
7.2 \\
7.4 \\
7.6 \\
7.8\end{array}$ & - & $\begin{array}{l}\text { 1. } 34501 \\
\text { 1. } 34530 \\
\text { 1. } 34560 \\
\text { 1. } 34589 \\
\text { 1. } 34619\end{array}$ \\
\hline $\begin{array}{l}8.0 \\
8.2 \\
8.4 \\
8.6 \\
8.8\end{array}$ & - & $\begin{array}{l}\text { 1. } 34648 \\
\text { 1. } 34677 \\
\text { 1. } 34706 \\
\text { 1. } 34736 \\
\text { 1. } 34765\end{array}$ \\
\hline 9.0 & . & 1. 34794 \\
\hline
\end{tabular}

\section{References}

[1] E. J. Pulaski, Chem. Eng. News 30, 2187 (1952).

[2] T. H. Evans and H. Hibbert, Bacterial polysaccharides, Advances in Carbohydrate Chem. 2, 209, (Academic Press, Inc., New York, N. Y., 1946).

[3] Polarimetry, saccharimetry, and the sugars, NBS Circular 440 , pp. 46 and 70 (1942).

[4] Report on sugars and sugar products, J. Assoc. Offic. Agr. Chemists [2] 36, 244 (1953).

[5] F. J. Bates and R. F. Jackson, Bul. BS 13, 118 (1916) S168; NBS Circular 440, p. 80 (1942).

[6] H. S. Isbell, C. F. Snyder, N. B. Holv, and M. R. Dryden, J. Research NBS 50, 81 (1953) RP2393.

Washington, May 17, 1954. 